\title{
A VERDADE AUTOBIOGRÁFICA DE BOYHOOD, DE J. M. COETZEE
}

\section{WESLEY MOREIRA DE ANDRADE*}

Universidade de São Paulo (USP), Programa de Pós-Graduação em Teoria Literária e Literatura Comparada (DTLLC), São Paulo, SP, Brasil.

Recebido em: 3 maio 2020. Aprovado em: 11 dez. 2020.

Como citar este artigo: ANDRADE, W. M. de. A verdade autobiográfica de Boyhood, de J. M. Coetzee. Cadernos de Pós-Graduação em Letras, v. 21, n. 1, p. 212-229, jan./abr. 2021. doi: 10.5935/cadernosletras. v21n1p212-229

\section{Resumo}

Este artigo analisa as especificidades de Boybood, de J. M. Coetzee, livro que inicia a trilogia Cenas da vida na província e rompe com as expectativas do leitor e com as convenções preestabelecidas de um texto de origem autobiográfica. Primeiramente, resgataremos dois livros exemplares da escrita de si que foram paradigmas para futuros trabalhos memorialísticos: Confissões, de Santo Agostinho, e Confissões, de Jean-Jacques Rousseau. Depois estudaremos mais detidamente Boyhood que, em razão da insistência de Coetzee em não vinculá-lo a um gênero específico e pelas opções estilísticas peculiares utilizadas na

* E-mail: wesleymandrade@gmail.com

(D) https://orcid.org/0000-0002-3376-5670 
construção do livro, continua intrigando leitores e especialistas em sua análise e fruição.

\section{Palavras-chave}

Autobiografia. J. M. Coetzee. Confissões.

\section{O PIONEIRISMO DE AGOSTINHO E ROUSSEAU}

“Alguém poderia ser artífice de si mesmo?”, reflete Santo Agostinho (2017, p. 39) no capítulo VI do livro primeiro de suas Confissões, ao relembrar as memórias mais remotas de sua infância. O filósofo reforça que, por essa época, já havia nele a necessidade de procurar "sinais para que os outros conhecessem meus sentimentos" (SANTO AGOSTINHO, 2017, p. 39). A intenção de resgatar em livro as reminiscências de sua vida pregressa é fato inédito para a literatura medieval de até então: um homem expor a si próprio em toda a sua verdade e transpor para o papel uma ação íntima e particular que estava associada ao ato confessional da religião católica apostólica romana. As Confissões, de Santo Agostinho, representam um marco nesse movimento que Charles Taylor (1997, p. 173) definiu como uma "linguagem da interioridade" para a investigação da trajetória pessoal em boa parte voltada àquilo que se passava nos recônditos da mente: os conflitos causados pela doutrina do maniqueísmo que ele seguia antes da conversão ao catolicismo, a culpa envolta em determinadas ações (como o roubo de peras que deixaram marcas em sua consciência), o caráter pecaminoso de sua vida boêmia, promíscua e errante.

Vemos, em cada linha das Confissões, um homem a revelar a sua essência mais humana e falha para um leitor que, como Deus onisciente, terá acesso a essa subjetividade nas páginas da obra que lê, mas que, antes de fazer um julgamento dos atos que testemunha, poderá reavaliar suas próprias atitudes e, também, alcançar Deus pela correção de seus atos ulteriores:

Com efeito, as confissões de minhas faltas passadas - que perdoaste e encobriste para que eu fosse feliz em ti, que mudas minha alma pela fé e pelo teu sacramento - tais confissões, quando lidas e ouvidas, despertam o coração para que não durma no desespero e diga "não posso" (SANTO AGOSTINHO, 2017, p. 252). 
A ação injuntiva sobre esse "leitor-testemunha-Deus" somente será alcançada de forma plena se for produto da busca de seu autor em relatar apenas a verdade: "Confessarei então o que sei de mim, confessarei também o que não sei de mim, porque, o que sei de mim, o sei pela tua iluminação, e o que não sei de mim, não o saberei até que minhas trevas se tornem como o meio-dia no teu rosto" (SANTO AGOSTINHO, 2017, p. 255, grifo do tradutor). Assim, a iluminação daquilo que há de mais obscuro com intento de uma redenção divina se faz por meio da rememoração dessas atitudes ditas pecaminosas e reprováveis com vias de que elas não se repitam num dado futuro e condicionam autor e leitor à procura por uma trajetória exemplar e mais santa que evita o caminho secular.

A prática de usar a escrita como um instrumento de reflexão do eu e como apoio memorialístico, de acordo com Michel Foucault (1992), era uma rotina exercida durante a Antiguidade Clássica com o objetivo de registrar no papel os maus pensamentos e os atos vindouros que representariam desvios de conduta, lembranças dos vacilos que aquele indivíduo ao menos pensou em cometer. Dessa forma, os pensamentos não estavam reservados ao claustro da mente. Foucault (1992, p. 131) afirma que "o constrangimento que a presença alheia exerce sobre a ordem da conduta, exercê-lo-á a escrita na ordem dos movimentos internos da alma"; redigir obrigatoriamente os maus pensamentos desempenha um papel "de um companheiro, ao suscitar o respeito humano e a vergonha” (FOUCAULT, 1992, p. 130). Exercício este que conduzia o sujeito à busca pela perfeição moral, pessoal e profissional e que foi adotado por diversas correntes de pensamento anteriores ao cristianismo, como o ascetismo.

Tradição retomada e singularizada por Santo Agostinho em seu anseio por uma retidão de caráter e uma santidade que deverá ser julgada por Deus, acima de tudo, validada pelo leitor que também se inspirará por essa busca e partirá para o mesmo projeto de autoconhecimento (por meio da experiência alheia) e de descoberta do poder e do amor de Deus como caminho incontornável e inevitável.

Essa exposição inédita de si próprio rendeu frutos diversos na literatura de cunho autobiográfico e culminou em outra obra paradigmática do gênero: Confissões, do escritor genebrino Jean-Jacques Rousseau. A intenção de revelar-se por completo nas páginas do livro assemelha-se ao empreendimento iniciado por Santo Agostinho séculos antes: "Dou começo a uma empresa de que não há exemplos, e cuja execução não terá imitadores. Quero mostrar aos 
meus semelhantes um homem em toda a verdade da natureza; e serei eu esse homem" (ROUSSEAU, 2008, p. 29).

O desejo de expor a verdade sobre si próprio levará o autor a primeiro pintar-se como um indivíduo em seus múltiplos defeitos. Rousseau evita, assim, o autoelogio de suas virtudes, projeto não completamente alcançado, como o próprio leitor verá nos livros que compõem essa obra autobiográfica: "Mostrei-me tal qual era: desprezível e vil quando o fui; bom, generoso, sublime, quando o fui; desnudei meu íntimo, tal como tu próprio o viste, Ente Eterno" (ROUSSEAU, 2008, p. 29). Essa verdade somente se consumará por via da recordação minuciosa de praticamente tudo que viveu até aquele momento em que porta a pena sobre o papel em branco: "Quereria poder de algum modo tornar minha alma transparente aos olhos do leitor; [...] proceder de modo que não haja um movimento que ele não perceba, enfim, de jeito que ele possa julgar por si próprio o princípio que o produz" (ROUSSEAU, 2008, p. 176).

O catálogo detalhado das memórias que Rousseau resgata o revelará em sua totalidade e evitará que ele, por via da omissão daquilo que pode resultar vergonha e embaraço, não honre o compromisso firmado no início do livro de revelar-se tal como foi: “Mas relatando-lhe com minúcias tudo o que me aconteceu, tudo que fiz, tudo que pensei, tudo que senti, não o posso induzir em erro, a menos que o queira" (ROUSSEAU, 2008, p. 176). Por conseguinte, não contar a plenitude de sua vida é o que Rousseau mais receia (e o consequente mau julgamento do leitor desse fracasso): "Só uma coisa tenho a temer nessa empreitada: não é dizer demais ou dizer mentiras, mas não dizer tudo ou calar verdades" (ROUSSEAU, 2008, p. 176).

Essa busca pela verdade difere-se da de Agostinho pela ausência de uma aprovação ou salvação divina como culminância. Não obstante, Rousseau posta-se como alguém que pode também induzir o leitor a ações mais virtuosas diante do relato dos muitos erros que ele cometeu e dos sucessos esporádicos que alcançou em sua vida pessoal e profissional; nas Confissões de Rousseau, a injunção vira prescrição no sentido de mostrar a quem lê uma série de condutas que, se seguidas, elevarão o leitor a semelhante posição.

Ao mesmo tempo, o autor de Emílio ou Da educação se põe desnudo aos olhos que percorrem sua obra mais famosa para ser julgado e, quiçá, obter o mesmo veredito que tem sobre si próprio: "A ele [o leitor] cabe reunir esses elementos e determinar o ser que os compõe: o resultado deve ser obra sua" (ROUSSEAU, 2008, p. 176). De acordo com Jean Starobinski (1991, p. 190, 
grifo do autor), todo o empreendimento autobiográfico e autorreflexivo de Rousseau não terá validade alguma se não exteriorizada, não basta para ele o perscrutar íntimo e o conhecer-se melhor ao longo desse processo, o que resultaria numa transparência unilateral:

[...] enquanto permanece estritamente "interior", enquanto não é acolhida pelos outros, ela é paradoxalmente uma transparência velada e solitária; não é uma transparência em ato, mas "em potência" [...]. Será transparência em ato somente quando tiver uma testemunha a quem aparecer como transparência, isto é, segundo a expressão de Rousseau, quando for transparente aos olhos do leitor.

Christopher Kelly (2001) é outro especialista que lança luzes a respeito dos objetivos de Rousseau em portar-se defectivo e, por isso mesmo, mais empático, que exercerá uma considerável ingerência sobre aquele que lê. As peripécias vividas e descritas por Rousseau ao longo de sua infância, juventude e atribulada vida adulta procuram:

[...] explicar como alguém pode ser transformado ou desnaturado por suas experiências sociais e, não obstante, encontrar-se ele próprio numa posição que the permite capturar o verdadeiro entendimento da natureza humana. Novamente Rousseau espera que o relato de sua própria experiência ajudará a reproduzir aquela experiência em alguns de seus leitores (KELLY, 2001, p. 324, tradução nossa).

Colocar-se como representação da natureza e da experiência humana funciona, desse modo, como um processo de descoberta em devir que se desnudará a um leitor que desbravará, pela vivência alheia, a sociedade contida naquelas páginas, sobre a qual o próprio Rousseau relatará as injustiças, os desenganos e as desilusões que viveu ao longo de sua rica trajetória.

Tanto Santo Agostinho quanto Jean-Jacques Rousseau marcaram seus nomes e suas obras na história da escrita de si; o gênero autobiográfico, desde então, passou por muitas transformações. Nos séculos posteriores, o revelar-se genuíno é uma preocupação que aos poucos deixa de conduzir as intenções de quem escreve, mudança de perspectiva que permite maiores arrojos estéticos na transposição das memórias pessoais para o papel.

A ficção, principalmente por meio do romance, ganha a primazia dos autores contemporâneos que pretendem apagar as fronteiras entre real e imaginário e expor a olhos nus as estruturas do texto literário numa atitude autor- 
reflexiva e metalinguística (quando a tradição anterior evitava e/ou negava essa faceta ficcional, estabelecendo um pacto de verossimilhança com o leitor daquilo que era informado ali no livro) ou refutar a vinculação do material escrito a somente uma dessas instâncias: vida ou arte (vide as obras que se vinculam à chamada autoficção). O sul-africano J. M. Coetzee é um desses entusiastas que tanto marcaram a literatura na heterogênea pós-modernidade do século XX.

\section{BOYHOOD: UMA AUTREBIOGRAFIA?}

Quando Boyhood foi publicado em 1997 pela Editora Secker \& Warburg, o livro que inicia a trilogia Cenas da vida na província (continuada depois, em 2003, por Youth e finalizada, em 2009, por Summertime) não apresentou indicações, na capa de sua primeira edição, sobre o gênero literário a que ele pertencia. Coetzee também não fazia qualquer afirmação a respeito em entrevistas e outros eventos públicos. Leitor e crítica especializada fariam as suas associações por conta própria: o livro traz esparsas menções ao sobrenome Coetzee; o protagonista de dez anos de idade é chamado pelo nome John (o mesmo prenome do autor de Desonra) apenas duas vezes; a narrativa é situada na África do Sul (terra natal do escritor) pós-eleição de Daniel François Malan, do Partido Nacionalista, entre outras informações que coincidem com fatos da biografia de J. M. Coetzee, nascido em 1940 e que teria a mesma idade do protagonista no período retratado em Boyhood.

Um ponto simultâneo de divergência e convergência seria justamente a linguagem empregada para dar forma a esse livro. Escrito na terceira pessoa e constituído, em sua maioria, por verbos conjugados no tempo presente, Boybood teria os requisitos para se distanciar, desse modo, do gênero autobiográfico. No entanto, essa linguagem não convencional para retratar a si próprio como um garoto em meio a uma África do Sul repleta de desigualdades já havia sido praticada, anos antes, em entrevista concedida por Coetzee a David Attwell e publicada no livro Doubling the point: essays and interviews. Nela, Coetzee (1992, p. 393, tradução nossa) refere a si próprio usando a terceira pessoa e emprega o verbo no present tense ao recordar uma passagem de sua infância na zona rural de Worcester, tal qual faria depois em Boybood: 
Seus anos na rural Worcester (1948-1951) como uma criança de um contexto africânder, comparecendo em aulas de inglês nível médio, em uma época de um nacionalismo africânder enfurecido, uma época quando leis estavam sendo criadas para prevenir pessoas de descendentes africânderes de trazerem seus filhos para falar inglês, provocando nele sonhos inquietos de ser perseguido e acusado: aos 12 anos, ele tem um bem desenvolvido senso de marginalidade social.

É nesse mesmo livro que Coetzee (1992, p. 294, grifos do autor), ao ser questionado a respeito de sua infância e juventude, utiliza uma expressão que, anos depois, seria posta em prática com a escrita e publicação da trilogia Cenas da vida na província e de outros romances que viriam a seguir: autrebiography - "ele começa agora a se sentir próximo ao eu: autrebiografia recua para a autobiografia". De origem francesa, a palavra autre significa "outro", ou seja, a biografia de um terceiro e não a de si próprio, estabelecendo, dessa forma, um curioso trocadilho com o gênero autobiográfico. Mas, se na entrevista ele afirma que, naquela época, deixou de ser esse "outro" e passou a viver a sua individualidade, em Boybood, como ressaltou Derek Attridge (2004, p. 143, tradução nossa), acontece um movimento reverso: "O uso da terceira pessoa dissocia implicitamente a voz narrativa da consciência narrada, dizendo-nos que essa era outra pessoa - que estamos lendo, para usar o termo de Coetzee, uma autrebiografia, não uma autobiografia”.

Então por que (se a intenção era autobiografar-se) retratar-se de tal maneira num gênero que, convencionalmente, solicita a expressão de um "eu" que narra, protagoniza e, coincidentemente, é o autor do livro que ali se encontra? Segundo Attridge (2004, p. 143, tradução nossa), o emprego desses recursos estilísticos, tão inesperados para uma autobiografia, é um jogo estabelecido por Coetzee com o leitor desde sua estreia literária com Dusklands e do qual ele não deseja abrir mão nem mesmo ao enveredar por um trabalho autobiográfico:

Em outras palavras, Coetzee conquista o mesmo efeito que encontramos em seus trabalhos ficcionais: ao leitor é recusado o conforto de um nível metanarrativo ou uma perspectiva a partir da qual julgamentos autorais (aqui, julgamentos sobre seu jovem "eu") poderiam ser feitos. Se a alguém é dada a responsabilidade pelos julgamentos do garoto de Boyhood, esse alguém é o leitor e o leitor é, portanto, implicado na teia ética através da obra. 
Sue Kossew (2014, p. 9), por sua vez, afirma que essa opção estética elusiva, que brinca com as fronteiras entre o que é real e o que é fictício, o que é autobiográfico ou não, apagando-as e pondo-as em xeque por meio de questões de autoridade e autoria, será recorrente e radicalizada nos romances posteriores de Coetzee. A especialista ainda ressalta que a técnica literária empregada pelo escritor sul-africano para "escrever sobre si como se fosse outro"

[...] obsessivamente direciona a atenção às convenções genéricas do escrever uma vida e às implicações éticas de semelhante escrita. Ao fazê-lo, ambos expõem a impossibilidade de representação da "verdade" em qualquer gênero, seja história, ficção ou biografia, e se engaja com o problema de autoridade que assombra toda a obra de Coetzee (KOSSEW, 2014, p. 9, tradução nossa).

Essa escolha estilística e formal vai na contramão de todo um repertório anterior da escrita de si, comprometido com aquilo que o francês Philippe Lejeune (2014) denominou de pacto autobiográfico. Para entendermos o pacto autobiográfico, é preciso resgatar a definição de "nome próprio" proposto por Lejeune (2014, p. 26-27) que o descreve como "única marca no texto de uma realidade extratextual indubitável, remetendo a uma pessoa real, que solicita, dessa forma, que lhe seja, em última instância, atribuída a responsabilidade da enunciação de todo o texto escrito". Autor-narrador-protagonista, portanto, estabelecem a identidade presente no texto que é responsável, respectivamente, pela escrita, enunciação e vivência dentro da obra autobiográfica, possibilitando o convênio firmado entre escritor e leitor da veracidade dos episódios narrados em livro. Apesar das características heterogêneas e fluidas da autobiografia, esse pacto autobiográfico, espécie de voto de confiança leitora, é conservado ao longo do período em que a leitura está sendo feita.

Apesar de o formato autobiográfico ser mais comum pela linguagem do romance em primeira pessoa, gênero que J. M. Coetzee domina como poucos, como o autor sul-africano trabalha e explora essas convenções apontadas por Lejeune, tão atreladas ao entendimento da verdade de um "eu" transportado para o texto literário, fazendo o uso do narrador na terceira pessoa (foco narrativo impessoal que ele poucas vezes experimentou em seus livros ficcionais anteriores)? O que pretende o autor de Vida e época de Michael K ao questionar essa verdade autobiográfica, ocultando-se e desviando-se de toda a atenção que deverá, então, ser canalizada para a obra pronta e aberta aos olhos do leitor? 
É conhecida uma de suas afirmações, em entrevista a David Attwell, em que ele ressalta que o ato de escrever não deixa de revelar aquele que redige, independentemente da intenção autobiográfica existente no trabalho que produz: "Deixe-me tratar isto como uma questão sobre dizer a verdade do que uma questão a respeito de uma autobiografia. Porque num amplo sentido toda escrita é autobiográfica: tudo que você escreve, incluindo crítica e ficção, te escreve enquanto você o escreve" (COETZEE, 1992, p. 17, tradução nossa). Ao mesmo tempo, Coetzee reforça, com essa atitude, a necessidade de desviar a atenção de si próprio, como autor e possível protagonista de seu livro, para o aspecto formal do texto. O texto ocupa o papel de protagonismo em seus escritos e, mesmo nos experimentos com a escrita de si da trilogia Cenas da vida na província, não abre mão dessa centralidade da matéria e da forma literária. O apuro estilístico do texto é o veículo encontrado por Coetzee para a transmissão dessa verdade. Aliás, é a única boia existente para o leitor se agarrar e sobreviver ao naufrágio dessas convenções.

\section{BOYHOOD: "EU" EMI TERCEIRA PESSOA}

Boyhood começa situando o leitor com a descrição do local onde a família de John mora na cidade de Worcester. O primeiro parágrafo se detém em revelar alguns aspectos da residência dos Coetzee que denotam também a atual situação financeira deles:

THEY LIVE ON A HOUSING ESTATE outside the town of Worcester, between the railway line and the National Road. The streets of the estate have tree-names but no trees yet. Their address is No. 12 Poplar Avenue. All the houses on the estate are new and identical. They are set in large plots of red clay earth where nothing grows, separated by wire fences. In each, back yard stands a small block consisting of a room and a lavatory. Though they have no servant, they refer to these as "the servant's room" and "the servant's lavatory". They use the servant's room' to store things in: newspapers, empty bottles, a broken chair, an old coir mattress (COETZEE, 1998, p. 1, grifos nossos).

1 Como estamos fazendo uma análise formal desse primeiro parágrafo de Boyhood, a citação será em sua língua original; para as outras menções, usaremos a tradução de Luiz Roberto Mendes Gonçalves feita para a editora Companhia das Letras: "ELES MORAM NUM CONJUNTO HABITACIONAL perto da cidade de Worcester, entre a estrada de ferro e a rodovia Nacional. As ruas do conjunto têm nomes 
Chama a atenção a maneira como o narrador se refere à família por meio do pronome pessoal "they" e do pronome possessivo "their", o que aumenta ainda mais a impessoalidade da escrita de J. M. Coetzee e o distanciamento do leitor dessas figuras que surgem durante a leitura, pondo-o em estado de atenção quanto ao material literário com o qual tem contato. Nota-se, também, o emprego de verbos conjugados no present tense ("live", "have", "is", "are", "grows", "stands", "refer", "use”) que dão uma sensação de imediatismo à descrição, como se o leitor estivesse presenciando aquela narrativa em tempo real.

Boyhood, como veremos a seguir, apesar do recurso ao narrador em terceira pessoa, não perde essa perspectiva mais infantil dos acontecimentos, em maior ou menor escala, da realidade sul-africana ou da dinâmica familiar e escolar (duas situações que ganham maior destaque pelo narrador neste livro); o que o leitor lê é o que protagonista presencia mediado por um narrador que evita a intromissão por meio de uma linguagem quase protocolar, mas não despida de ironia em alguns momentos. O foco do livro é voltado às impressões que o jovem protagonista possui dos espaços por onde circula, das pessoas com quem estabelece contato, dos juízos de valor que o menino faz de familiares e amigos mais próximos.

Quando se refere aos pais, o narrador reforça o quão John é crítico e até mesmo impiedoso com seus progenitores. Nem a mãe, com quem John possui um relacionamento mais próximo, é poupada dos julgamentos do garoto. $\mathrm{O}$ comportamento superprotetor dela enfada o protagonista, que começa a sentir-se sufocado por esse olhar vigilante e percebe a necessidade de livrar-se dessa dependência o quanto antes. Aceitar incondicionalmente esse amor e carinho oriundos da presença materna somente aumentaria a sensação de que estaria em débito diante dessas atitudes e as quais se obrigará a retribuir um dia:

0 amor cego dela, devastador, autossacrificante por ele e pelo irmão, mas especialmente por ele, o perturba. Gostaria que ela não o amasse tanto. Ela o ama absolutamente; portanto, ele deve amá-la absolutamente: essa é a lógica que ela Ihe impõe. Jamais será capaz de retribuir todo o amor que ela despeja sobre ele. A ideia de uma vida inteira subjugado por uma dívida de amor o

de árvores, mas ainda não têm árvores. O endereço deles é avenida dos Choupos número 12 . Todas as casas do conjunto são novas e idênticas. Estão situadas em grandes lotes de terra argilosa e vermelha onde nada cresce, separadas por cercas de arame. Em cada quintal há uma pequena edícula que consiste em um quarto e um banheiro. Apesar de não terem empregada, eles se referem àquilo como 'o quarto de empregada' e 'o banheiro de empregada'. Usam o quarto de empregada para guardar coisas: jornais, garrafas vazias, uma cadeira quebrada, um velho catre de couro" (COETZEE, 2010, p. 5, grifos nossos). 
enfurece a ponto de não querer beijá-la, de recusar-se a ser tocado por ela. Quando ela se afasta em silencioso sofrimento, ele deliberadamente enrijece o coração, recusando-se a ceder (COETZEE, 2010, p. 46).

A mãe também é responsável pelo sentimento de alheamento que John mantém em relação aos amigos que possui, devido ao tratamento especial dado ao filho que o impede, segundo ele próprio, de levar uma vida normal e priva-o de experiências que seus colegas de escola já tiveram, tornando-o um corpo estranho em meio ao grupo geral:

[...] ele sente raiva da mãe por não ter filhos normais e não lhes dar uma vida normal. 0 pai, caso assumisse o comando, os transformaria numa família normal. Seu pai é normal em todos os sentidos. Ele é grato à mãe por protegê-lo da normalidade do pai, quer dizer, das ocasionais e ingênuas crises de raiva e das ameaças de surra. Ao mesmo tempo tem raiva da mãe por transformá-lo numa coisa esquisita, uma coisa que precisa ser protegida para continuar vivendo (COETZEE, 2010, p. 11).

O alvo dessa aversão à normalidade mencionada é o pai. Sua presença em casa, diante do protagonismo do garoto no ambiente caseiro, é acessória e, de acordo com a visão do protagonista, prescindível:

NUNCA ENTENDEU qual era a posição do pai na casa. Na verdade, não fica claro com que direito o pai está lá. Numa casa normal, ele consegue entender, o pai é o chefe: a casa the pertence, a mulher e os filhos vivem sob seu comando. Mas no caso deles, assim como no das duas irmãs de sua mãe, são a mulher e os filhos que formam o núcleo, enquanto o marido não passa de um apêndice, alguém que contribui economicamente como se fosse um inquilino (COETZEE, 2010, p. 15).

Todo esse desprezo tem origem na ausência paterna durante os primeiros anos de infância de John: o pai fora lutar na Segunda Guerra Mundial deixando mãe e filhos sobrevivendo em um apartamento de poucos cômodos, numa situação financeira precária, privação que contribuiu para o estreitar dos laços entre mãe e filho:

Mesmo antes de conhecer o pai, isto é, antes que ele voltasse da guerra, já tinha decidido que não iria gostar dele. Em certo sentido, portanto, a antipatia é abstrata: ele não quer ter um pai, ou pelo menos não quer um pai que more na mesma casa (COETZEE, 2010, p. 42). 
O pai também foi o ponto-chave para a mudança da família para a cidade de Worcester e o consequente declínio econômico dela. Outrora, o pai trabalhava num cargo público de cobrador de aluguéis. Membro do Partido Unido, ele perdeu o cargo após a eleição de Daniel François Malan em 1948, candidato rival do Partido Nacional Africano, fato que alimentou a antipatia do garoto pela figura do então líder sul-africano, responsável igualmente pelo banimento da publicação de suas revistas em quadrinhos favoritas:

Tem uma imagem do dr. Malan gravada na mente. 0 rosto redondo do dr. Malan não tem compreensão ou piedade. Seu papo pulsa como o de um sapo. Tem os lábios franzidos.

Ele não esqueceu a primeira medida do dr. Malan em 1948: banir todas as revistas do Capitão Marvel e do Super-Homem, permitindo que apenas os quadrinhos com personagens animais, cuja intenção é manter as crianças como bebês, passassem pela alfândega (COETZEE, 2010, p. 66).

Malan foi responsável pela institucionalização do apartheid, regime de segregação da população negra que vigorou por décadas. O apartheid não é citado diretamente pelo narrador, porém o personagem principal testemunha e se incomoda com cenas de exclusão, preconceito e desigualdade social. Como no dia em que resolveu comemorar o aniversário com alguns colegas numa lanchonete, porém a presença do lado de fora do estabelecimento de garotos negros que assistiam, curiosos, à interação entre John e os amigos acabou estragando a experiência deles:

Ele se sente soberano, distribuindo prazeres daquele jeito; a ocasião seria um sucesso, se não fossem as crianças de cor, maltrapilhas, paradas junto à vitrine, olhando para eles.

Nos rostos daquelas crianças não vê sinal do ódio que, como está preparado para reconhecer, ele e seus amigos merecem por ter tanto dinheiro, enquanto elas não têm um centavo (COETZEE, 2010, p. 68).

Não podemos esquecer que, apesar da recusa em fazer da obra literária um instrumento de denúncias da realidade sul-africana de até então, Coetzee, que sempre foi criticado por essa atitude refratária, diversa de outros escritores conterrâneos mais engajados como Nadime Gordimer e André Brink, nunca deixou de abordar os temas mais polêmicos e urgentes de seu país em livros mais conhecidos. Conforme ressaltou Jane Poyner (2009, p. 1 tradução nossa), percorrem de variados modos na obra de J. M. Coetzee 
[...] temas e questões pertinentes às situações (pós) coloniais e do apartheid: discurso colonial, o outro, segregação racial, censura, proibição e exílio, brutalidade e tortura policial, liberalismo sul-africano e ativismo revolucionário, o lugar das mulheres, o relacionamento do povo da África do Sul com a terra e, não menos importante, a política ética da escrita, todos figuram proeminentemente na obra.

Poyner (2009, p. 7, tradução nossa) chama a atenção que essa realidade se faz articulada e mediada por uma linguagem arrojada que não perde a centralidade em detrimento da temática abordada na obra literária, o leitor terá, ao mesmo tempo, uma experiência de choque com a realidade disposta naquelas linhas e uma experiência estética igualmente não confortável, mas instigadora:

É nessa complexa união entre estética e temática que leitores de Coetzee se veem mais recompensados, nenhum aspecto sendo comprometido pelo outro. Embora os protagonistas-escritores na obra se engajem com as tensões aparentes entre arte e política, a textualidade elaborada das ficções sugere que Coetzee se recusa completamente a endossar o ético-político, negando o literário.

Apesar da ausência da expressão de um eu que conta a própria existência, descolando, assim, a figura fictícia infantil da presença empírica do escritor, encontramos passagens nas quais o protagonista, além de compreender os espaços pelos quais circula e as atitudes contraditórias de familiares e amigos, tenta interpretar a si próprio e o turbilhão de sentimentos e dúvidas que o acometem nessa fase da vida. Em diversos momentos de Boybood, o protagonista é atormentado pelos próprios segredos que guarda sobre ele mesmo: a escolha dentro da escola pela religião católica (não praticada pelos pais em casa), a predileção pelos russos, num período de polarização por causa da Guerra Fria, e também o desejo despertado pela contemplação das pernas dos garotos que cruzam o seu caminho. Segredos que o perturbam porque não pode exteriorizá-los e sequer sente-se à vontade de compartilhar com colegas e parentes:

Parece que sempre alguma coisa dá errado. Tudo o que ele quer, tudo de que gosta, mais cedo ou mais tarde tem de virar segredo. Ele começa a pensar em si mesmo como uma daquelas aranhas que vivem num buraco no chão com um alçapão. A aranha precisa ficar sempre recuando para o buraco e fechando o alçapão, se isolando do mundo, se escondendo (COETZEE, 2010, p. 28). 
Esse admirar coisas diferentes dos garotos de sua idade (ou diversas daquilo que é senso comum) e o calar essas preferências são maneiras de preservar essa individualidade excêntrica diante dos outros. A metáfora da aranha reclusa, usada pelo narrador, retrata perfeitamente esse comportamento arredio e autocentrado de John que contribui ainda mais para a procura de distanciamento e o desejo de libertação dos núcleos de convivência (o familiar, por exemplo) que justamente colaboram para a repressão de suas idiossincrasias.

Esses momentos de perscrutação interior e a busca por entender as próprias peculiaridades aproximam, mesmo que, em Boyhood, a abordagem esteja distante de uma idealização, das passagens mais confessionais das obras escritas por Santo Agostinho e Jean-Jacques Rousseau.

John encontra-se dentro da narrativa entre os dez e treze anos, numa fase de transição entre infância e adolescência, e começa a sentir os efeitos dessa transformação dentro dele e o faz sentir-se uma anomalia em meio aos ambientes escolar e caseiro, como vemos no trecho a seguir:

Tem a sensação de ser defeituoso. Tem a sensação de que alguma coisa em seu interior está se rompendo lentamente: um muro, uma membrana. Tenta se controlar ao máximo para manter esse rompimento dentro de limites. Para mantê-lo nos limites, e não para impedi-lo: nada poderá impedi-lo (COETZEE, 2010, p. 12-13).

Um dos fatores que pesam no deslocamento de John é a língua inglesa, que aprende em sua classe, sendo ele um dos melhores alunos da turma, e também falada por seus pais. O domínio do inglês, em vez do africânder praticado por outros colegas e pela família paterna, contribui ainda mais para o sentimento de exclusão e de diferença que John possui de si mesmo em relação aos colegas.

Por falarem inglês em casa e por sempre ser o primeiro da classe em inglês, ele se considera inglês. Embora seu sobrenome seja africânder, embora o pai seja mais africânder que inglês, embora ele mesmo fale africânder sem sotaque inglês, jamais poderia passar por um africânder. Seu vocabulário de africânder é escasso e frágil; existe um denso mundo de gírias e expressões dominadas pelos verdadeiros meninos africânderes - do qual as obscenidades são apenas uma parte - a que ele não tem acesso (COETZEE, 2010, p. 114).

Esse acesso vedado ao universo e à língua africânder, apesar de reforçar a impressão de isolamento do protagonista, não interfere na predileção dele pelo 
idioma do colonizador, o inglês, e não muda a percepção que tem sobre o dialeto de seus antepassados que ele compara com a fala de "um escravo chicoteado" (COETZEE, 2010, p. 48). Tanto que um de seus maiores temores é o de ser transferido da turma inglesa na qual está matriculado para uma turma africânder, uma vez que o seu sobrenome denuncia o vínculo, mesmo que rarefeito, a esse grupo; fato que, se concretizado, o levaria a abandonar a escola e preferir o suicídio. De acordo com Vera Lucia Harabagi Hanna (2016, p. 116-117), o dilema dessa cidadania fracionada entre o inglês e o africânder, com propensão explícita ao primeiro idioma, "Deixa transparecer certo constrangimento, não exatamente vergonha, na preferência da língua; embora tenha desejo de ser inglês, ele contradiz seu sentimento de pertencimento em relação à família”. Hanna (2016, p. 117) ainda chama a atenção para o modo como o protagonista observa e avalia os garotos africânderes, que possuem modos mais brutos e cujo "comportamento que ele não lograva compartilhar, evitava encontros, verdadeiramente os temia”.

Marginalizado pela proteção excessiva materna e pela inexpressividade e falta de autoridade do pai, que não impõe ao protagonista uma vivência parecida como a dos outros garotos, John sente-se ainda mais deslocado pelo domínio fluente da língua inglesa. Conforme afirmou Dominic Head (2009), por mais que vislumbre uma persona anglófona para si, ele sabe que não se encaixa nem como inglês, pela origem africânder da família e pelo país onde nasceu e vive, e nem como africânder, por não ter crescido e sido alfabetizado e letrado como um deles efetivamente, diferentemente dos meninos de sua idade que o praticam no cotidiano.

Como vimos, um aspecto crucial da identidade de Coetzee, amplificado nesse livro, em seu status bilíngue tanto como falante africânder e inglês, mas pertencendo a uma família que claramente se desassocia do grupo africânder. Essa é a forma de um autoexílio que os coloca às margens da vida sul-africana, desde que "africano" e "africânder" tornaram-se polos importantes entre os quais tomou lugar a desavença política na última metade do século XX. Ainda há também ambição social na filiação dos pais e em suas escolhas para educar Coetzee em na língua inglesa (HEAD, 2009, p. 4, tradução nossa)

Por sua vez, Jenny Fredman (2007, p. 13, tradução nossa) observa que esse conflito identitário também lança luzes sobre a maneira como John enxerga a si próprio: 
0 nível de simpatia de John não é muito alto. Suas ações costumam sugerir que ele as executa apenas para deixar claro que é melhor do que os outros. No entanto, às vezes, sua alteridade o coloca numa posição mais vulnerável do que se ele fosse como seus pares.

Nesse caso, sentir-se estranho em relação aos outros tanto pode colocá-lo numa situação inferior, o que não é uma constante ao longo do romance, como esse perceber-se diferente, surge como um fator de distinção e superioridade.

Dessa maneira, o narrador não impede o leitor de ter uma visão que desabone o protagonista. Apesar de criança, John apresenta opiniões honestas e é retratado em seus inúmeros defeitos. Descrito como uma fraude, como alguém que precisa o tempo todo esconder-se e guardar segredo de suas preferências e atitudes, ao não reprimir a sinceridade do que pensa do pai e da mãe e o desejo de desprender-se deles o quanto antes, as ações autorreflexivas do protagonista auxiliam, junto com a linguagem em terceira pessoa e verbos no presente, a efetivar esse distanciamento entre leitor e personagem, que enxerga aquele garoto com menor simpatia e, todavia, torna aquela figura mais verossímil aos olhos de quem lê.

\section{CONSIDERAÇÕES FINAIS}

Iniciamos este artigo com a breve explanação das Confissões (e menção a elas) escritas por Santo Agostinho e Jean-Jacques Rousseau justamente porque a busca pioneira desses escritores por um retrato completo e fidedigno de si próprios e do contexto nos quais se situavam serve de contraponto ao que foi e é praticado por muitos autores do século XX em diante, quando empreendem trabalhar com a matéria autobiográfica. O estatuto de verdade é posto de lado pela contemporaneidade ou colocado em contínua e proposital suspensão axiomática.

É o caso de Boyhood e de significativa parte da obra de J. M. Coetzee. Por mais que saibamos que a origem desse trabalho reside nas memórias infantis do escritor sul-africano, não podemos comprová-las como inatacáveis, e o próprio escritor se exime de assumir semelhante compromisso. Cabe ao leitor, diante de um refratário narrador em terceira pessoa, fazer as suas conjecturas e assinar um contrato com o autor, pacto este cujas cláusulas não são muito claras, oferecem risco e, também, claro, seduzem com uma oferta de realidade 
que não pode ser cumprida de forma integral, mas cuja fatura certamente não trará maiores arrependimentos.

\section{The autobiographical truth of J. M. Coetzee's Boyhood}

\section{Abstract}

This article analyses the specificities of J. M. Coetzee's Boybood. This book starts the Scenes from provincial life trilogy and breaks the reader's expectation and the pre-established conventions of a text with an autobiographical origin. First, we will recover two exemplary books of the self that were paradigms to the future memorialist works, Saint Augustine's Confessions and Jean-Jacques Rousseau's Confessions. After that, we will closely study Boyhood that, due to Coetzee's insistence in don't bind it to a specific genre and for the peculiar stylistic options used in the book's construction, intrigue readers and specialists in their analysis and fruition.

\section{Keywords}

Autobiography. J. M. Coetzee. Confessions.

\section{REFERÊNCIAS}

ATTRIDGE, D. J. M. Coetzee and the ethics of reading: literature in the event. Chicago: The University of Chicago Press, 2004.

COETZEE, J. M. Doubling the point: essays and interviews. Edited by David Attwell. Cambridge: Harvard University Press, 1992.

COETZEE, J. M. Boyhood: scenes from provincial life. London: Vintage Books, 1998. COETZEE, J. M. Infância: cenas da vida na província. Tradução Luiz Roberto Mendes Gonçalves. São Paulo: Companhia das Letras, 2010.

FOUCAULT, M. A escrita de si. In: FOUCAULT, M. O que é um autor? Tradução Antônio Fernando Cascais e Eduardo Cardeiro. Lisboa: Passagens, 1992. p. 129-160.

FREDMAN, J. “All autobiography is storytelling, all writing is autobiography”: Autobiography and the Theme of Otherness in J.M. Coetzee's Boyhood: Scenes from Provincial Life. Växjö: Växjö University, 2007. Disponível em: https://www.researchgate. net/publication/279678334. Acesso em: 19 abr. 2021. 
HANNA, V. L. H. A experiência do cotidiano em J. M. Coetzee: língua e identidade em Boyhood, scenes of a provincial life, a memoir (1998). Todas as Letras, São Paulo, Edição Especial, p. 111-124, 2016. doi: 10.5935/1980-6914/letras.especial.p111-124. Acesso em: 25 set. 2018.

HEAD, D. The Cambridge introduction to J. M. Coetzee. New York: Cambridge University Press, 2009. (Cambridge introductions to literature).

KELLY, C. Rousseau's confessions. In: RILEY, Patrick (ed.). The Cambridge Companion to Rousseau. Cambridge: Cambridge University Press, 2001. p. 302-328.

KOSSEW, S. Scenes from provincial life (1997-2009). In: MEHIGAN, T. (ed.). A companion to the works of J. M. Coetzee. New York: Camdem House, 2014. p. 9-22.

LEJEUNE, P. O pacto autobiográfico. In: LEJEUNE, P. O pacto autobiográfico: de Rousseau à internet. Organização Jovita Maria Gerheim Noronha; tradução Jovita Maria Gerheim Noronha, Maria Inês Coimbra Guedes. Belo Horizonte: Editora UFMG, 2014. p. 15-55.

POYNER, J. J. M. Coetzee and the paradox of postcolonial authorship. Wey Court East: Ashgate, 2009.

ROUSSEAU, J.-J. Confissões. Tradução Rachel de Queiroz e José Benedicto Pinto. Bauru: Edipro, 2008. (Clássicos Edipro).

SANTO AGOSTINHO. Confissões. Tradução do latim e prefácio Lorenzo Mammi. 1. ed. São Paulo: Companhia das Letras, 2017. (Penguin Classics).

STAROBINSKI, J. Os problemas da autobiografia. In: STAROBINSKI, J. Jean-Jacques Rousseau: a transparência e o obstáculo; seguido de sete ensaios sobre Rousseau. Tradução Maria Lúcia Machado. São Paulo: Companhia das Letras, 1991. p. 187-207.

TAYLOR, C. In interiore homine. In: TAYLOR, C. As fontes do self: a construção da identidade moderna. Tradução Adail Ubirajara Sobral e Dinah de Abreu Azevedo. São Paulo: Edições Loyola, 1997. p. 169-187. 